\title{
Entrepreneurs' Social Network and Entrepreneurial Optimism
}

\author{
Dong Liu ${ }^{\mathrm{a}}$, Aizhen $\mathrm{Wu}^{\mathrm{b}}$ and Xiaohu Zhou ${ }^{\mathrm{c}}$ \\ School of Economics and Management, Nanjing University of Science and Technology, \\ Nanjing 210094, China. \\ a631013027@qq.com, b1805340253@qq.com, c925537218@qq.com
}

\begin{abstract}
Keywords: Social network, entrepreneurial optimism, entrepreneurial self-efficacy.
\end{abstract}
\begin{abstract}
Social network can not only provide entrepreneurs with resources and material support, but also psychological, emotional and other soft support, which is of great benefit to the mental health of entrepreneurs and their persistence to overcome all kinds of difficulties. In order to explore the influence of the social network on entrepreneurial optimism, we used SPSS, AMOS and other statistical analysis software to analyze the data obtained from 204 Chinese entrepreneurs. Results of the current study demonstrate a positive relationship between social network and entrepreneurial optimism. Entrepreneurial self-efficacy play a positive moderating role in the relationship. This paper has implications for the study of social networks and entrepreneurial positive emotions and puts forward some relevant suggestions.
\end{abstract}

\section{Introduction}

With the upsurge of entrepreneurial boom, entrepreneurial positive emotion has become a hot topic of entrepreneurship research [1]. Researchers have found that entrepreneurs are more optimistic than those who work as employees. And just as Jack Ma said, the best quality of successful entrepreneurs is always optimistic. Thus, entrepreneurs need to have the spirit of optimism. Therefore, it is of great significance to study entrepreneurial optimism.

Entrepreneurship is a process of constantly putting resources into creating value, and it has been proved that the construction and development of social network to support entrepreneurial behavior is the key factor for the success of entrepreneurs. In recent years, individual social network has become a new research hotspot in the field of entrepreneurship. Scholars are used to explain the social network to provide resources and material support for entrepreneurs[2].However, Entrepreneurial process is highly emotional, which need entrepreneurs invest time, energy, effect and so on[3]. There is a lack of research on the soft support provided by the social network for new entrepreneurs. And the soft support is essential for the establishment and development of new start-ups. At the same time, the entrepreneurial self-efficacy and entrepreneurial environment will influence the transformation of this soft support provided by the social network.

\section{Theory and Hypotheses}

\subsection{Social Networks and Entrepreneurial Optimism.}

Compared to the rigid support of social networks for entrepreneurs, the soft support provided by social networks is less concerned. However, many studies have shown that optimism is associated with social networks. Carver et al (2002) found that optimistic people were better able to deal with stressful events because they had a broader social network, could attract more potential partnerships and useful social network nodes than pessimists. Entrepreneurial optimism represents a positive expectation, which is linked to a wider social relationship (MacLeod Conway, 2005), optimism is associated with the advantages of social resources and the network of relationships, including general social relationships and more intimate relationships (Carver et al., 2010)[4]. Sequeira et al (2007) shows that the strong relationship between individuals can provide strong spiritual support to individuals, and the strong relationship comes from the social network of individuals [5]. Xiaohu Zhou and Junhua Sun (2014) suggest that social network can provide new entrepreneurs with soft 
support such as psychological, spiritual and cognitive, which can breed social psychological strength. Entrepreneurial psychological capital is very important, and optimism is the typical psychological characteristics of entrepreneurs. In the entrepreneurial process, optimistic and positive attitude can help entrepreneurs overcome some difficulties and maintain confidence in the future under challenging and uncertain environment. In the context of Chinese "relationship" society, the influence of social capital (network) on entrepreneurial activities is critical is especially obvious. More social network resources can provide enterprises convenience to raise funds, sale products and services, thereby improving the entrepreneurial expectations of entrepreneurial success. Thus, we put forward the hypothesis:

Hypothesis 1: The entrepreneurial social network has a significant positive impact on entrepreneurial optimism.

\subsection{The Moderating Effect of Entrepreneurial Self-Efficacy.}

Many studies have shown that entrepreneurial self-efficacy plays an important role in the formation of entrepreneurial intention (Kolvereid, 1996:Autietal, 1997). According to Ajzen (1975) "belief -attitude-intention-behavior" framework, as a deep faith, entrepreneurial self-efficacy is an important concept to reveal key entrepreneurial activities [6]. Entrepreneurial optimism will be affected by individual beliefs. Chen (1998) et al. find that individuals with a higher level of entrepreneurial self-efficacy are more capable and confident when faced with uncertain risks and challenges. Baum (1995) found that entrepreneurial self-efficacy is a major factor influencing entrepreneurial intention and development of firm. The entrepreneurial process is heavily complex, and entrepreneurs need to interpret and make decisions quickly when facing all kinds of complicated social resources and social relations [7]. Individuals with higher entrepreneurial self-efficacy are more likely to achieve this requirement, and can rely on higher entrepreneurial intentions to achieve their goals. Chinese scholars Wei Fan, Chongming Wang(2005) shows that potential entrepreneurs who are more confident of their ability will be more confident in the business success, which indicates that individuals with strong entrepreneurial self-efficacy are more inclined to produce entrepreneurial optimism. Thus, we put forward the hypothesis:

Hypothesis 2: Entrepreneurial self - efficacy positively moderates the relationship between social network and entrepreneurial optimism.

\section{Methods}

\subsection{Sample and Procedure.}

Chinese entrepreneurs with a business founded less than eight years were invested in the current study. The questionnaire survey lasted five months, including pre-survey and formal investigation the two stages. First, in the pre-survey phase, 50 questionnaires were issued, and 35 were recovered, of which 30 valid questionnaires, the effective recovery rate of the questionnaire was $85.71 \%$. Secondly, in the formal investigation stage, a total of 260 questionnaires were distributed. Excluding the samples which were unqualified, we finally got 204 valid questionnaires.

\subsection{Measures.}

We measured social network from social network structure and social network function two dimension, following the work of Ning Sun (2011), Burt (1992) and Reagans\& McEvoy (2002).Social network structure scale includes13 items, and social network function scale includes 23 items, thus a total of 36 items. We took a 7-point scale, ranging from 1 (strongly disagree) to 7 (strongly agree).The measure produced a Cronbach's coefficient alpha of .875 in the current study. Entrepreneurial optimism was measured using Luthans \& Youssef's (2004) optimism scale, and we put it in the specific situation of entrepreneurship. Just as the title: "at work, when faced with uncertain things, I usually look forward to the best results ", and in current study the item is"During entrepreneurial process, when faced with uncertain things, I usually look forward to the best results ".Entrepreneurship optimistic scale included a total of six items, and the measure produced a Cronbach's coefficient alpha of .698 in the current study. We measured entrepreneurial self-efficacy following the work of Baughn (2006) and Forbes (2005). There were six items in the scale, which were scored using the Likert seven-point scale. The Cronbach's alpha coefficient of reliability 
was .818. Based on previous studies, we controlled entrepreneurs' age, gender, marriage and highest education, as well as entrepreneurial experience, initial capital, family background and corporate nature as control variables.

\subsection{Data Analysis.}

Multiple regression analysis was used as the main statistical procedure for examining the relationship between social network and entrepreneurial optimism, also the proposed moderating effect of entrepreneurial self-efficacy. And we use SPSS20.0 statistical package for data analysis.

\section{Result}

Table 1 shows the means, standard deviations, and bivariate correlations of the study variables. Table 2 presented the multiple regression models, including main effect and the moderating effect of.

Table 1. Correlations of This Study

\begin{tabular}{|c|c|c|c|c|c|c|c|c|c|c|c|}
\hline Variable & 1 & 2 & 3 & 4 & 5 & 6 & 7 & 8 & 9 & 10 & 11 \\
\hline 1 & 1 & & & & & & & & & & \\
\hline 2 & $-.587 * *$ & $.303 * *$ & 1 & & & & & & & & \\
\hline 3 & 0.059 & -0.149 & $\begin{array}{c}- \\
0.086\end{array}$ & 1 & & & & & & & \\
\hline 4 & 0.018 & -0.087 & $\begin{array}{c}- \\
0.060\end{array}$ & 0.006 & 1 & & & & & & \\
\hline 5 & $-.210^{*}$ & 0.150 & 0.152 & -0.033 & 0.115 & 1 & & & & & \\
\hline 6 & $.235 * *$ & -0.152 & $\begin{array}{c}- \\
0.099\end{array}$ & 0.144 & 0.083 & $\begin{array}{c}- \\
0.116\end{array}$ & 1 & & & & \\
\hline 7 & -0.086 & -0.053 & $\begin{array}{c}- \\
0.016\end{array}$ & -0.143 & 0.093 & $\begin{array}{c}- \\
0.085\end{array}$ & $-.371 * *$ & 1 & & & \\
\hline 8 & 0.121 & -0.020 & $0 . \overline{126}$ & $.227 * *$ & 0.03 & $\begin{array}{c}- \\
0.089\end{array}$ & 0.100 & $-.168^{*}$ & 1 & & \\
\hline 9 & 0.107 & -0.005 & $0 . \overline{-}$ & 0.121 & 0.025 & $\begin{array}{c}- \\
0.147\end{array}$ & $.178^{*}$ & -0.058 & $.308^{* * *}$ & 1 & \\
\hline 10 & 0.053 & $-.192 *$ & $0 . \overline{-}$ & $.216^{* * *}$ & 0.074 & $\begin{array}{c}- \\
0.089\end{array}$ & 0.16 & -0.045 & $.330^{* *}$ & 0.081 & 1 \\
\hline 11 & -0.043 & 0.056 & 0.092 & $.226^{* *}$ & $\begin{array}{c}- \\
0.075\end{array}$ & $\begin{array}{c}- \\
0.005\end{array}$ & 0.078 & -0.148 & $.528 * *$ & $.230^{* *}$ & $.330 * *$ \\
\hline
\end{tabular}

Note. $\mathrm{N}=204.1=$ age, $2=\operatorname{sex}, 3=$ marriage, $4=$ highest education, 5=corporate nature, $6=$ entrepreneurial experience, $7=$ initial capital, $8=$ family background, $9=$ social network, $10=$ entrepreneurial optimism, $11=$ entrepreneurial self-efficacy. $* \mathrm{p}<.10, * * \mathrm{p}<.05, * * * \mathrm{p}<.01$.

In Hypothesis 1 we propose that the entrepreneurial social network has a significant positive impact on entrepreneurial optimism. From model 2 in Table 2, we can see the relationship between social network and entrepreneurial optimism is positive and positive $(\beta=0.279$, Sig. $=0.001)$. Thus, Hypothesis 1 is supported. Hypothesis 2 states that entrepreneurial self-efficacy positively moderates the relationship between social network and entrepreneurial optimism. As shown in Model 3 of Table 3 , the interaction of entrepreneurial self-efficacy with social network is significant and positive for entrepreneurial optimism $(\beta=0.289$, Sig. $=0.000)$. Thus, Hypothesis 2 is supported. 
Table 2. Results of Hierarchical Regression Models

\begin{tabular}{|c|c|c|c|c|c|c|c|c|c|}
\hline \multirow[b]{2}{*}{ Variable } & \multicolumn{3}{|c|}{ Model 1} & \multicolumn{3}{|c|}{ Model 2} & \multicolumn{3}{|c|}{ Model 3} \\
\hline & $\mathrm{B}$ & $\beta$ & $\mathrm{p}$ & B & $\beta$ & $\mathrm{p}$ & B & $\beta$ & $\mathrm{p}$ \\
\hline (Constant) & 4.478 & & 0.000 & 2.515 & & 0.013 & 2.280 & & 0.018 \\
\hline Age & 0.070 & 0.056 & 0.600 & 0.055 & 0.044 & 0.668 & 0.074 & 0.059 & 0.550 \\
\hline Sex & 0.139 & 0.070 & 0.436 & 0.108 & 0.055 & 0.53 & 0.039 & 0.020 & 0.812 \\
\hline Marriage & -0.007 & -0.004 & 0.972 & 0.037 & 0.021 & 0.84 & 0.012 & 0.007 & 0.945 \\
\hline $\begin{array}{l}\text { Highest } \\
\text { education }\end{array}$ & 0.097 & 0.103 & 0.229 & 0.044 & 0.047 & 0.577 & 0.046 & 0.048 & 0.550 \\
\hline $\begin{array}{c}\text { Corporate } \\
\text { nature }\end{array}$ & 0.016 & 0.031 & 0.716 & 0.009 & 0.016 & 0.843 & -0.010 & -0.019 & 0.813 \\
\hline $\begin{array}{l}\text { Entrepreneurial } \\
\text { experience }\end{array}$ & -0.219 & -0.128 & 0.146 & -0.176 & -0.103 & 0.226 & -0.100 & -0.058 & 0.479 \\
\hline Initial capital & 0.062 & 0.145 & 0.129 & 0.063 & 0.147 & 0.109 & 0.059 & 0.136 & 0.121 \\
\hline $\begin{array}{c}\text { Family } \\
\text { background }\end{array}$ & 0.008 & 0.005 & 0.954 & 0.071 & 0.047 & 0.603 & 0.124 & 0.082 & 0.349 \\
\hline $\begin{array}{l}\text { Social network } \\
\text { Socia network }\end{array}$ & & & & 0.396 & 0.279 & 0.001 & 0.411 & 0.289 & 0.000 \\
\hline $\begin{array}{c}\times \\
\text { Entrepreneurial } \\
\text { self-efficacy }\end{array}$ & & & & & & & 0.512 & 0.289 & 0.000 \\
\hline $\mathrm{R} 2$ & & 0.063 & & & 0.134 & & & 0.212 & \\
\hline Adjusted R2 & & 0.008 & & & 0.076 & & & 0.153 & \\
\hline $\mathrm{F}$ & & 1.143 & & & 2.299 & & & 3.580 & \\
\hline
\end{tabular}

\section{Conclusion}

Bardon (2008) pointed out that entrepreneurs who often have a positive experience are more likely to recognize entrepreneurial opportunities because of their wide range of attention, strong divergence of mind, and high alertness to new opportunities [8]. By means of social network theory and entrepreneurial cognition theory, this paper explores the relationship between social network and entrepreneurial optimism. The results of this study show that the social network contributes to the formation of entrepreneurial optimism, and the entrepreneurs' entrepreneurial self-efficacy plays a catalytic role in the transformation of social network to entrepreneurial optimism. The current research has implications for the study of social networks and entrepreneurial positive emotions. Also, we provides some suggestions for the promotion of entrepreneurial activities in practice. First, potential entrepreneurs should actively build and develop their own social networks, to form their own relationship resources with a variety of possible platforms. They should also participate in some entrepreneurship training and related business learning to enhance their own entrepreneurial selfefficacy to form moderate and realistic optimism. Second, China actively encourage innovation and entrepreneurship nowadays, so the government and the community should create the conditions. The government should strive to build a wide range of public entrepreneurship platform, business incubator, public space, etc., and take more effective measures to encourage new entrepreneurs to participate in cooperation and sharing.

\section{Acknowledgments}

This paper was supported by the Project of the National Natural Science Foundation of China (71172102/G0201). 


\section{References}

[1]. Cardon M S, Gregoire D A, Stevens C E, et al. Measuring entrepreneurial passion: Conceptual foundations and scale validation $\boldsymbol{z}_{[}[\mathrm{J}]$. Journal of Business Venturing, 2013, 28(3):373-396.

[2]. Semrau T, Seniorer A W. How Exactly Do Network Relationships Pay Off? The Effects of Network Size and Relationship Quality on Access to Start-Up Resources [J]. Entrepreneurship Theory and Practice, 2014, 38(3):501-525.

[3]. Cardon M S, Wincent J, Singh J, et al. The Nature and Experience of Entrepreneurial Passion [J]. Academy of Management Review, 2016, 34(34):511-532.

[4]. Carver C S, Scheier M F, Segerstrom S C. Optimism.[J]. Clinical Psychology Review, 2010, 30(7):879.

[5]. Carr J C, Sequeira J M. Prior family business exposure as intergenerational influence and entrepreneurial intent: A Theory of Planned Behavior approach [J]. Journal of Business Research, 2007, 60(10):1090-1098.

[6]. Hmieleski K M, Baron R A. Entrepreneurs'optimism and Hew venture performance:A social cognitive perspective[J]. Academy of Management Journal, 2009, 52(3):473—488

[7]. Burger J M, Messian N, Patel S, et al. What a coincidence! The effects of incidental similarity on compliance.[J]. Personality and Social Psychology Bulletin, 2004, 30(1):35.

[8]. Baron R A. The Role of Affect in the Entrepreneurial Process [J]. Academy of Management Review, 2008, 33(2):328-340. 